Introduction to

International Relations

Editor: Linda Brady, Georgia Institute of Technology

Contributors:

Diddy R. M. Hitchins, University of Alaska

Stephen R. Newlin, California State University, Chico

Charles Lipson, University of Chicago

Timothy J. Lomperis, Duke University

Barbara Welling Hall, Earlham College

Janie Leatherman, Helsinki University

Kenneth Lieberthal, University of Michigan

Raymond Duvall, University of Minnesota

Richard L. Clinton, Oregon State University

George F. Steger, Saint Mary College

Jane E. Holl, United States Military Academy

Suresht R. Bald, Willamette University

\section{Introduction to Political Theory}

Editor: Peter G. Stillman, Vassar College

Contributors:

Bill Chaloupka, University of Montana

Ron Christenson, Gustavus Adolphus College

David Schaefer, Holy Cross College

E. V. Wolfenstein, University of California, Los Angeles

Marilyn A. Davis, Spelman College

Emily R. Gill, Bradley University

Edward A. Stettner, Wellesley College

Jean Bethke Elshtain, Vanderbilt University

Nancy Rosenblum, Brown University

Benjamin R. Barber, Rutgers

University

Peter Freedman-Doan, University of Michigan

Stephen Macedo and B. Honig, Harvard University

James W. Muller, University of Alaska

Isaac Balbus, University of Illinois, Chicago

Alfonso Damico, University of Florida
Dan Sabia, University of South Carolina

James Schmidt, Boston University

Clark E. Cochran, Texas Tech University

J. Peter Euben, University of California, Santa Cruz

John E. Lawyer, Jr., Bethel College

This winter and spring, the syllabi collections are being reviewed by faculty and departments who expressed an interest in doing so. They will provide comments on the utility of the collections for preparing graduate students to teach undergraduates and as a reference for all faculty. Additional copies of the first edition of these syllabi collections are available from the APSA for $\$ 5.00$ each.

The titles and the editors for the five course syllabi collections being prepared in the current academic year are:

\section{Public Law}

Lief H. Carter, University of Georgia

Methodology

John R. Freeman and W. Phillips

Shively, University of Minnesota

Public Administration

Naomi B. Lynn, Sangamon State University

Political Behavior

Nancy H. Zingale, University of St. Thomas

\section{Capstone Course/Senior Seminar Ronald Kahn, Oberlin College}

Faculty who are interested in reviewing these collections, which will be published in early fall 1992 , should write to: Course Syllabi Review/APSA, 1527 New Hampshire Avenue, N.W., Washington, DC 20036.

\section{Section News}

\section{Political Organizations and Parties}

The Political Organizations and Parties Section again plans to hold a workshop on Wednesday afternoon preceding the 1992 APSA meeting in
Chicago. The substantive topic of the workshop will be announced in the Summer issue of $P S$ as well as the POP newsletter. The thrust of the workshop will again be on research issues and methodologies and speakers will include both academics and practitioners. Members who have specific suggestions for topics or concerns that might be addressed in the workshop should contact Ruth Jones at (602) 965-6551 or ATRSJ@ ASUACAD immediately.

\section{Representation and Electoral Systems}

The Section on Representation and Electoral Systems held its annual meeting in Washington, D.C. on August 30, 1991, and elected Professor Bernard F. Grofman of the University of California, Irvine, as chairman for a term of two years.

Elected members of the Executive Committee were Carol Cassell of the University of Alabama; Lorn Foster of Pomona College; Louis Fraga of Stanford University; Bernard Grofman of the University of California, Irvine; Lawrence D. Longley of Lawrence University; Georgia Persons of Georgia Institute of Technology; Wilma Rule of the University of Nevada, Reno; and Joseph F. Zimmerman, State University of New York at Albany.

Bernard F. Grofman, Chairman of the George H. Hallett Book Award Committee, presented the 1991 Award to Professor Hannah F. Pitkin of the University of California, Berkeley, for The Concept of Representation, published by the University of California Press in 1967. The Award is presented annually to the author of a book published more than ten years ago that has made a lasting contribution to the literature.

Dennis Anderson, Chairman of the Best Paper Committee, presented the Award to Mark Rush of Washington and Lee University for his paper entitled "The Variability of Partisanship and Turnout," which was presented at the Association's 1990 annual meeting.

Members voted to establish student membership dues of $\$ 3.00$ annually. 